The Land of Britain:

the Report of the Land Utilisation Survey of Britain. Edited by Dr. L. Dudley Stamp. Part 78: Berkshire. By J. Stephenson, with an Historical Section by W. G. East. Pp. 113. (London : London Utilisation Survey of Britain, 1936.) 2s. $6 d$.

THE publication of the first of the contemplated eighty-seven county reports on the utilization of the land of Great Britain gives an idea of the scope and value of the work. The report begins with a summary of the geographical background, geology, relief, soils and climate. Then follow accounts of the distribution of woodland, arable land and grassland, which are closely correlated with physical conditions and illustrated with distributional maps. Next comes the distribution of orchards and poultry farming and lastly the distribution of settlements and population in general.

The report brings out not merely the present use of the land but also indicates the changes that have taken place chiefly through the operation of economic factors. Thus to-day the arable land of Berkshire covers 26.5 per cent of the county, while in 1808 , and for many years subsequent, it appears to have covered more than fifty per cent. The process of putting arable land down to grass is still continuing. On the other hand, arable farming would appear to be concentrating in the areas best suited to that use. This tendency is accentuated by better transport, which helps to nullify advantage of position, and uniform wages which reduce the ability of poor areas with low wages to compete with better land. $\mathrm{Mr}$. Stephenson concludes by dividing the county into agricultural regions each with its own characteristics and potentialities, and he notes that Berkshire is in a transitional stage common to all counties near London. Price conditions are changing the aspects of farming, and growth of population and transport are making the east and south more and more into residential areas.

The report concludes with a valuable article by Mr. W. G. East on the utilization of the land about 1800 .

\section{Wild Flowers of the Wayside and Woodland}

Compiled by T. H. Scott and W. J. Stokoe, based upon the Standard Work "Wayside and Woodland Blossoms" by Edward Step. Pp. $352+81$ plates. (London and New York : Frederick Warne and Co., Ltd., 1936.) 7s. 6d. net.

THIs attractive book will prove very useful to the field naturalist rather than to the academic student of systematics. It is well produced, and is of a size convenient for the pocket. Such a book, well printed and beautifully illustrated, is just that type which helps the intelligent man to a truer appreciation of the country, while at the same time giving a valuable insight into the beauties of Nature. It should, therefore, give full satisfaction to the country rambler interested, if only mildly, in the surrounding flora. Apart from this, however, it will provide an excellent introduction to a later more serious study of systematic botany.
The book opens with a short description of the more common forms of leaves, and this is illustrated by two pages of line diagrams. Next follows a short dissertation on the forms of flowers, illustrated by a typical flower and line diagrams of the more common types of inflorescences. A short glossary of botanical terms helps the reader to follow more easily the descriptions in the greater part of the book.

An unusual and helpful feature then follows : forty pages are devoted to line diagrams of common flowers, grouped according to the colours, white or whitish, and shades of pink, red, yellow, blue, purple, lilac, green and brown.

The bulk of the book is occupied by a description of the most common plants in the British flora. This occupies about 250 pages, interspersed with eighty coloured plates each portraying about four types of flowers. There is an index.

This book is to be unreservedly recommended, and, in view of the amount of subject matter and coloured illustrations which it contains, it is excellent value for the price demanded.

\section{The Heavens and Faith}

By the Rev. M. Davidson. Pp. $x v+162$. (London: Watts and Co., 1936.) 5s. net.

THE impact of the science of astronomy upon the Christian faith is a topic which has been dealt with by a number of writers, but Dr. Davidson is better equipped than many, because he is at once a clergyman and an astronomer, Sir Frank Dyson testifying in a foreword to his competence in this science. But, what is not less important, Dr. Davidson has not only the requisite knowledge, but also the necessary candour, apart from which all discussion ends with foregone conclusions.

The problems set for religious faith by modern astronomy are threefold : (1) the apparent indifference of an incredibly vast universe to man and his destiny; (2) how to reconcile the three-storey universe of Creeds and Scripture with present scientific knowledge; and finally (3) what we are to make of the eschatological beliefs entertained not only by Paul and the primitive Church, but also, as is now recognized by scholars, by the Founder of Christianity himself. Most works of orthodox apologetic tackle (1) and (2) with varying degrees of success, but there is a widespread tendency to ignore (3) altogether, in spite of its vital importance. Dr. Davidson, however, does not evade this issue, nor seek to obscure the point that the ethic of the Sermon on the Mount had a very definite basis of apocalyptic belief which is no longer held. How far its validity may be thereby affected is a matter for serious inquiry and not for dogmatic assertions. As a matter of fact, if we believe that the world is soon to end and be replaced by a better, the ethic of the Sermon is mere common-sense, and not fantastic idealism, as it appears to most 'world-accepting' citizens to-day.

This book was very well worth writing, and will repay study. 